\title{
Upper Gastrointestinal Endoscopy in Children's Abdominal Pains in Ivory Coast
}

\author{
Aboubacar Demba Bangoura', Henriette Ya Anzouan Kissi-Kacou' ${ }^{1}$, Denis Coffi Fanou ${ }^{1}$, \\ Dimitry Guillaume Kouamé ${ }^{1}$, Stanislas Doffou ${ }^{1}$, Constant Assi ${ }^{2}$, Alassan Kouamé Mahassadi ${ }^{1}$, \\ Alain Koffi Attia ${ }^{1}$, Aya Thérèse N'dri-Yoman ${ }^{1}$ \\ ${ }^{1}$ Hepatogastroenterology Unit, Yopougon Teaching Hospital, Yopougon, Ivory Coast, Coate d'Ivoire \\ ${ }^{2}$ Hepatogastroenterology Unit, Cocody Teaching Hospital, Cocody, Ivory Coast, Coate d'Ivoire \\ Email: bangousmed@gmail.com
}

How to cite this paper: Bangoura, A.D., Kissi-Kacou, H.Y.A., Fanou, D.C., Kouamé, D.G., Doffou, S., Assi, C., Mahassadi, A.K., Attia, A.K. and N'dri-Yoman, A.T. (2016) Upper Gastrointestinal Endoscopy in Children's Abdominal Pains in Ivory Coast. Open Journal of Gastroenterology, 6, 397405.

http://dx.doi.org/10.4236/ojgas.2016.612042

Received: November 14, 2016

Accepted: December 9, 2016

Published: December 12, 2016

Copyright $\odot 2016$ by authors and Scientific Research Publishing Inc. This work is licensed under the Creative Commons Attribution International License (CC BY 4.0).

http://creativecommons.org/licenses/by/4.0/

\begin{abstract}
Since a longtime considered as functional and psychological, children's abdominal pains (CAP) is a public health problem. Advances in digestive endoscopy and Helicobacter pylori ( $H$. pylori) discovery have reignited the debate of the organicity of CAP. The aim of this study is to determine the diagnosis rentability of upper gastrointestinal endoscopy (UGIE) in CAP in Ivory Coast. Patients and Methods: This a retrospective analytical study based on reports of UGIE performed in 2 university hospital and 3 private clinics of Abidjan from march 2007 to march 2016. The children (from 1 day to 15 years) in which UGIE were performed for abdominal pains were included in the study. Results: 116 UGIE were performed in children for abdominal pains during the study period. Epigastric pain was the main indication of UGIE (88\%). The diagnosis rentability of UGIE was more than $70 \%$ in this study. The main anomalies observed in UGIE were gastropathies. Ulcers were rarely found. Conclusion: UGIE play an important diagnosis role in CAP in Ivory Coast. However gastric biopsies for Helicobacter pylori research are not common practice in our country.
\end{abstract}

\section{Keywords}

Upper Gastrointestinal Endoscopy, Children's Abdominal Pains, Gastropathies, Helicobacter pylori, Ivory Coast

\section{Introduction}

The abdominal pains represent a common reason for pediatric consultation. They are particularly frequent among the school-age children and adolescents 
[1] [2]. Since a longtime, the majority (90\%) of children's abdominal pains (CAP) are considered as functional [3]. However, with the development of upper gastrointestinal endoscopy (UGIE) in pediatric gastroenterology, the organic origin of CAP increased under $10 \%$ to over $50 \%$ [4]. UGIE or gastroscopy is a test that allows visual exploration of the inner walls (mucosa) of the esophagus, the stomach and the duodenum to detect anomalies, and sample tissues (biopsies) for histological study [5].

Several studies [5]-[10] have showed that abdominal pains are the most frequent indications of UGIE in children in African countries with frequencies ranging from $22 \%$ to $90 \%$. Moreover, the identification of Helicobacter pylori ( $H$. pylori) as a major cause of chronic gastritis and peptic ulcer in children highlights the important diagnosis of UGIE in CAP [11] [12] [13]. Despite its invasive nature, the interest of gastroscopy is twofold. It allows the diagnostic of gastroduodenal lesions and to research $H$. pylori infection. Some authors [14] [15] [16] have found endoscopic anomalies in CAP with frequencies ranging from $18 \%$ to $70 \%$. In Asia Quarq [14] has found 18\% of endoscopic anomalies, in Europe Ashorn [15] 58.5\% and in West Africa Lawson [16] 70\%.

In Ivory Coast, studies have been done in UGIE in children [5] [17] but no study was interested in UGIE in CAP.

The aim of this study is to determine the diagnosis rentability of gastroscopy in children's abdominal pains (CAP) in Ivory Coast.

\section{Patients and Methods}

This is a retrospective analytical study based on reports of upper gastrointestinal endoscopy (UGIE) performed in 2 university hospital and 3 private clinics in Abidjan over a period of 7 years (from march 2009 to march 2016). The children (aged from 1 day to 15 years) in which UGIE were performed for abdominal pains during the study period were included in the study. The patients aged over 15 years and children in which UGIE were performed for some over indications during the study period were excluded from the study.

The children included in the study were distributed in 4 groups according to age: New born (from 0 to 28 days), Infant (from 29 days to 23 months), Small children (from 2 to 6 years), Child (from 6 to 12 years) and Adolescents (13 to 15 years).

We have grouped under the terms of abdominal pains, any kind of recurrent abdominal pains that motived the performance of UGIE or gastroscopy (epigastric pain, ulcer syndrome, dyspeptic syndrome, retrosternal pains, abdominal pains poorly systematized).

For each child's record included in the study, we provided the informations as follows:

-Demographic data: age, gender.

-Clinical data: the kind of abdominal pain that motived the performance of 
gastroscopy.

-Results of upper gastrointestinal endoscopy.

-Performance or not of biopsies (site of biopsies and their indication)

-The results of histological examination (presence or not of $H$. pylori).

All of these data were collected using a survey sheet developed for the study.

For each patient included in the study UGIE was considered beneficial when lesions were found or when UGIE was normal and $H$. pylori infection was found in histological examination of gastric biopsies.

\section{Limitation of the study:}

The first limit is the fact that it is a retrospective study carried out in 5 centers of endoscopy with practices sometimes different. The low rate of systematic gastric biopsies for H. pylori infection research does not allow to know the real prevalence of this infection in our study.

\section{Results}

The authors showed that 116 upper gastrointestinal endoscopies (UGIE) were performed in children for abdominal pains during the study period.

These 116 UGIE accounted over $42 \%$ of all upper gastrointestinal endoscopies performed in children during the study period. The age of our children ranged from 15 month to 15years with a mean age of 11.88 year and a median of 12.5 years. Teenagers and school-age children were the most represented age group with frequencies of $49.13 \%$ and $46.55 \%$. The small children and infant accounted less than $5 \%$ of the study population. Moreover it was noted a female predominance with a sex ratio male/female of 0.50 (Table 1).

From a clinical view, epigastric pains were the common indication for gastroscopy realization in $88 \%$ of the cases (Table 1 ).

The diagnosis rentability of UGIE in children's abdominal pain was more than $70 \%$. The examination was normal in $30 \%$ of cases and lesions were found in $70 \%$ of cases (Table 2). The most common site of lesions was gastric (89.18\%).

The main anomalies observed in UGIE were gastropathies (53.15\%). They were frequently localized in the antrum $(70.78 \%)$ and rarely in the fundus (5\%). The erythematous type was most common endoscopic aspect of these gastropathies $(66 \%)$. The nodular type represented only $18 \%$ of the gastropathies (Table 3).

Beside to these superficial lesions (gastropathies), the bile reflux was the second endoscopic anomalie observed in our children with abdominal pains (Table 2). Ulcers were rarely found with a frequency of $2.70 \%$ for bulbar ulcer and $0.90 \%$ for gastric ulcer (Table 2).

Biopsies were performed in only 37 children out of 116 (31.89\%). Almost all of these biopsies were sampled from the stomach ( 3 antral, 2 fundic, 1angular) to search chronic Helicobacter pylori (H. pylori) gastritis.

Histological examination of biopsies revealed chronic $H$. pylori gastritis in 
$63 \%$ of examined sample.

This infection was found as well in cases of normal mucosa as mucosal anomalies observed in gastroscopy (Table 4).

Table 1. Sociodemographic and clinical characteritics of our study population.

\begin{tabular}{lcc}
\hline \multicolumn{1}{c}{ Characteristics } & Number $(\boldsymbol{n})$ & Percentage (\%) \\
\hline Sociodemographic characteristics: & & \\
Age group & 57 & 49.13 \\
Adolescent & 54 & 46.55 \\
Child & 3 & 2.58 \\
Small children & 2 & 1.72 \\
Infant & & \\
& 39 & 33.63 \\
Mex $\quad 77$ & 66.37 \\
Female & 0,50 & \\
Sex ratio (male/female) & & 88 \\
Clinical characteristics & 102 & 12 \\
Epigastric pains & 14 & \\
Other abdominal pains & & \\
\hline
\end{tabular}

Others abdominal pains (retrosternal pains, abdominal pains poorly systematized)

Table 2. Upper gastrointestinal endoscopy finding in children's abdominal pains.

\begin{tabular}{ccc}
\hline & Number $(n)$ & Percentage (\%) \\
\hline Normal findings & 35 & 30 \\
${ }^{1}$ Stomach & 99 & 89.18 \\
Gastropathy & 59 & 53.15 \\
Bile reflux & 39 & 38.78 \\
Gastric ulcers & 1 & 0.90 \\
${ }^{2}$ Duodenum & $\mathbf{8}$ & 7.20 \\
Duodenitis & 5 & 4.50 \\
Duodenal ulcers & 3 & 2.70 \\
${ }^{3}$ Others lesions & 6 & 3.60 \\
\hline
\end{tabular}

${ }^{3}$ Others lesions ( 3 cases of reflux oesophagitis, 1 case of oesophageal mycoses, 2 cases of incompetent cardial)

Table 3. Distribution of gastropathies depending on their seat and aspects.

\begin{tabular}{ccccc}
\hline & Antrum (n) & Fundus (n) & Antrum and fundus (n) & Total \\
\hline Erythematous gastropathy & 30 & 2 & 5 & 37 \\
Nodular gastropathy & 10 & 0 & 1 & 11 \\
Congestive gastropathy & 1 & 1 & 4 & 06 \\
Erosive gastropathy & 2 & 0 & 0 & 02 \\
Total & 43 & 3 & 10 & 56 \\
\hline
\end{tabular}


Table 4. Histological examinations results of gastric biopsies examined.

\begin{tabular}{cccc}
\hline & H. pylori positive $n(\%)$ & H. pylori negative $n(\%)$ & Total $n(\%)$ \\
\hline Normal mucosa & $11(63 \%)$ & $7(37 \%)$ & $18(100)$ \\
Mucosa anomalies & $12(64 \%)$ & $7(36 \%)$ & $19(100)$ \\
Total & $23(63 \%)$ & $14(37 \%)$ & $37(100)$ \\
\hline
\end{tabular}

\section{Discussion}

The recurrent abdominal pains are a public health problem among children because affecting $15 \%-45 \%$ of school-age children [13] [18]. The etiologies of these pains are considered as functional and psychological in nearly $90 \%$ of cases. Only $10 \%$ of these pains have an organic origin. Advances in digestive endoscopy and $H$. pylori discovery have reignited the debate of organicity of children's recurrent abdominal pains. Some authors found $18 \%$ and $58 \%$ of organic causes with the digestive endoscopy. The aim of this multicenter study is to determine the rentability diagnosis of upper gastrointestinal endoscopy in children's abdominal pains in our country.

The 116 UGIE performed in children for abdominal pains accounted over $42 \%$ of UGIE performed in children during the study period. These results show that abdominal pains are the main indications of UGIE in several developing countries as Lawson [6], and Okello [9] reported. The age of our children ranged from 15 month to 15 year with a mean age of 11.88 years and median of 12.5 years. In this study, teenagers and school-age children were the most represented age group as in several similar studies [1] [13] [18] [19]. Indeed, for Lifschit these pains are a frequent cause of UGIE performance in children after 7 years [20]. Moreover it was noted a female predominance with a sex ratio male/female of 0.50 probably related to the demographic distribution of the ivorian population by sex [21].

From a clinical view, epigastric pains were the common indications for gastroscopy realization in $88 \%$ of cases.

The chronic gastritis and peptic ulcer manifested mainly by epigastric pains as Attia [22], Bougouma [23], Maiga [24], Perret [25] and Sanguino [26] showed.

The diagnosis rentability of UGIE in this study was more than $70 \%$. A similar rentability was found by Lawson in his study [16]. However, in other series of literature, this rentability was low from $3.6 \%$ to $28 \%$ [27] [28]. The observed differences are probably due to the studied populations and the high frequency of epigastric pains in our study (88\%).

The most commonly observed lesions were gastropathies (53.15\%) as in many developing countries studies where epigastric pains were the main indication of UGIE [6] [9] [10] [29] [30]. The high frequency of gastropathies in these studies is correlated to the high prevalence of $H$. pylori infection in developing countries $(60 \%-80 \%)$. In Ivory Coast, it varies from $53 \%$ to $91 \%$ [31] [32] [33]. In the industrialized countries, particularly in France where the prevalence of this infec- 
tion is low $5 \%-10 \%$ [34], two studies [35] [36] found $8.64 \%$ and $13 \%$ of gastropathies.

These results show that $H$. pylori is the first etiological factor of chronic gastritis as Attia [22], Bougouma [23], Diomandé [33] reported. This difference of prevalence between the developed and developing countries is the result of socioeconomic differences between these two worlds; the poor are more vulnerable to infection [37] [38].

The predominant antral topography $(76.78 \%)$ of gastropathies is due to the natural history of $H$. pylori infection. Despite the high prevalence of $H$. pylori infection in our country, the nodular gastropathy described as specific of $H$. $p y$ lori infection [39] accounted only $18 \%$ of gastropathies.

Bile reflux, second endoscopic anomaly observed in our children with abdominal pains could be linked to vomiting efforts during gastroscopy as Assi [17] signified.

Ulcers were rarely found with a frequency of $2.70 \%$ for bulbar ulcer and $0.90 \%$ for gastric ulcer according to the literature data [27] [40].

Despite the high prevalence of $H$. pylori in our context, gastric biopsies for his research are not common practice. Only $31 \%$ children have benefited from these biopsies. This low rate of systematic gastric biopsies for $H$. pylori infection research is in contradiction with the current recommendations [39]. The breath test (13C-UBT) may be an alternative to gastric biopsies for $H$. pylori infection research but it is not common in our developing country.

Histological examination found an $H$. pylori infection in $63 \%$ of gastric biopsies examined. This infection was found as well in case of normal mucosa as mucosa anomalies. These finding clearly show that there is not parallelism between endoscopy and histology, and they must arouse among endoscopist doctors systematic gastric biopsies to research $H$. pylori in children seen in upper gastrointestinal endoscopy for abdominal pains.

Helicobacter pylori ( $H$. pylori) infection is strongly associated to children's abdominal pains [1]. The eradication of $H$. pylori allows the improvement of symptoms [41] [42] and to prevent evolutionary complications of this infection (peptic ulcer and gastric cancers).

\section{Conclusion}

Upper gastrointestinal endoscopy plays an important role in the diagnosis of children's abdominal pains in Ivory Coast. However the gastric biopsies to research $H$. pylori infection are not common practice. They must be aroused among the endoscopist doctors for a better management of children's abdominal pains in our country with a high prevalence of $H$. pylori infection.

\section{References}

[1] Kalach, N. and Benhamou, P.H. (2002) Diagnostic et modalités de la prise en charge 
des douleurs abdominales récidivantes de l'enfant. La lettre de l'hépatogastroentérologue, $\mathrm{n}^{\circ} 3$, vol. V, mai-juin.

[2] Turck, D. (1998) Douleurs abdominales chroniques de I'enfant. Rev Prat (Paris), 48, 369-375.

[3] Gottrand, F. (2001) Diagnostic d'une douleur abdominale. Médecine thérapeutiquel pédiatrie, 4, 213-216.

[4] Lopez Alonso, M., Moya, M.J., Cabo, J.A., Riba, S.J., Del Carmen, M.M. and Silny, J. (2006) Twenty for Esophageal, Impedance PH Monitoring in Healthy Preterm Neonates: Weakly Acidic and Weakly Alkaline Gastro-Esophageal Reflux. Pediatrics, 118, 793-794. https://doi.org/10.1542/peds.2005-3140

[5] Bangoura, A.D., Anzouan-Kacou, H.Y.K., Doffou, S., Assi, C., Bathaix, M.F.Y., Attia, A.K. and Ndri-Yoman, A.T. (2016) Upper Gastrointestinal Endoscopy and Children Digestive Pathology in Abidjan. Open Journal of Gastroenterology, 6, 265274.

[6] Lawson-Ananissoh, L.M., Bouglouga, O., Bagny, A., Kaaga, L., EL Hadj yakoubou, R. and Redah, D. (2015) Panorama des affections oesogastroduodénales chez les enfants de moins de 20ans au Togo. Médecine d'afrique Noire, 62, No. 7.

[7] Alatise, O.I., Anyabolu, H.C., Sowande, O. and Akinola, D. (2015) Paediatric Endoscopy by Adult Gastroenterologists in Ile-Ife, Nigeria: A Viable Option to Increase the Access to Paediatric Endoscopy in Low Resource Countries. African Journal of Paediatric Surgery, 12, 261-265 https://doi.org/10.4103/0189-6725.172568

[8] Mudawi, H.M., El Tahir, M.A., Suleiman, S.H., Eltaybe, N.H., Gamer, N.M., Abdallha, F.A. and Ibrahim, S.Z. (2009) Pediatric Gastrointestinal Endoscopy: Experience in a Sudanese University Hospital. Eastern Mediterranean Health Journal, $15,1027-1031$.

[9] Okello, T.R. (2006) Upper Gastrointestinal Endoscopic Findings in Adolescents at Lacor Hospital, Uganda. African Health Sciences, 6, 39-42.

[10] Kawami, E., Machado, R.S., Fonseka, J.R., et al. (2004) Clinical and Histological Features of Duodenal Ulcer in Children and Adolescents. Jornal de Pediatria, 80, 321-325. https://doi.org/10.2223/JPED.1207

[11] Mougenot, J.F., Faure, C. and Goulet, O. (2001) Endoscopie Digestive 2001 EMC Pédiatrie 4-017-A-05. Gastroentérologie, 9-013-B-07, 26 p.

[12] Gottrand, F. (2000) Place d'Helicobacter pylori dans les douleurs abdominales de l'enfant. Archives de Pédiatrie, 7, 197-200. https://doi.org/10.1016/S0929-693X(00)88091-4

[13] Hassall, E. and Dimmick, J.E. (1991) Unique Features of Helicobacter pylori Disease in Children. Digestive Diseases and Sciences, 36, 417-423. https://doi.org/10.1007/BF01298868

[14] Quark, S.H., Lam, S.K. and low, P.S. (1990) Upper Gastrointestinal Endoscopy in Children. Singapore Medical Journal, 31, 123-126.

[15] Ashorn, M., Maki, M., Ruuska, T., et al. (1993) Upper Gastrointestinal Endoscopy in Recurrent Abdominal Pain of Childhood. Journal of Pediatric Gastroenterology and Nutrition, 16, 273-277. https://doi.org/10.1097/00005176-199304000-00009

[16] Lawson-Ananissoh, L.M., Bouglouga, O., Bagny, A., EL-Hadji Yakoubou, R., Kaaga, L. and Redah, D. (2014) Apport de la fibroscopie digestive haute dans l'exploration des épigastralgies. Journal de la Recherche Scientifique de P Universite de Lome, 16, 213-219. 
[17] Assi, C., Thot'o, A.S., Eloumou, G., Lohouès, M.J. and Camara, B.M. (2010) Endocopie digestive haute pédiatrique: Une expérience hospitalière en côte d'ivoire. Médecine Tropicale, 70, 4.

[18] American Academy of Pediatrics Subcommittee on Chronic Abdominal Pain (2005) North American Society for Pediatric Gastroenterology Hematology, and Nutrition. Chronic Abdominal Pain in Children. Pediatrics, 115, e370-e381.

[19] Mouterde, O. (2011) Douleurs abdominales chroniques de l'enfant: Point de vue du gastroenterologue. Archives de Pédiatrie, 18, H146-H147. https://doi.org/10.1016/S0929-693X(11)71010-7

[20] Lifshitz, C.H. (1994) Indications de l'endoscopie du tractus digestif supérieur, chez le nourrisson, l'enfant, et l'adolescent. Acta Endoscopica, 24, 125-128. https://doi.org/10.1007/BF02963237

[21] CIA World Factbook (2014) Version de 31 Mars 2015. Profil de la population ivoirienne en 2014.

[22] Attia, K.A., N'dri Yoman, T., Diomandé, M.I., Mahassadi, A., et al. (2001) Clinical, Endoscopic and Histologic Aspects of Helicobacter pylori Gastritis in Cote d'Ivoire: Study of 102 Patients. Bulletin de la Société de Pathologie Exotique, 94, 5-7.

[23] Bougouma, A., Ilboudo, D., Sangaré, L., Diomandé, I., et al. (1997) Aspects épidémiologiques et cliniques de l'infection à Helicobacter pylori en zone tropicale à propos de 150 cas. Medecine d'Afrique Noire, 44, 24-28.

[24] Maiga, M.Y., Traoré, H.A., Diarra, M., Pichard, G., et al. (1996) Etude anatomoclinique des gastrites chroniques au Mali. Medecine d'Afrique Noire, 43, 268-272.

[25] Perret, J.L. and Nguemby-Mbina, C. (1991) Aspects épidemiologiques, cliniques et évolutifs des ulcères gastroduodénaux chez les sujets Gabonais. Medecine d'Afrique Noire, 38, 828-832.

[26] Sanguino, J., Costa, J.S., Charrua, B., Mata, E., Mirones, J. and Quina, M. (1990) Gastrites Chroniques-Traduction Clinique? Medicine et Chirurgie Digestives, 19, 205-207.

[27] Boudabbous, M., Gargouri, L., Chtourou, L., Mnif, L., Amouri, A. and Tahri, N. (2014) Indications et apport de la fibroscopie digestive haute chez l'enfant. A propos de 592 cas. Journal Africain d' Hépato-Gastroentérologie, 8, 125-129. https://doi.org/10.1007/s12157-014-0531-2

[28] Ganga-Zandzou, P.S., Ategbo, S., Michaud, L., et al. (1997) Neonatal esophagogastro-duodenoscopy. A propos of 123 examinations performed on 107 newborn infants. Archives de Pédiatrie, 4, 320-324. https://doi.org/10.1016/S0929-693X(97)86447-0

[29] Joshi, J.R., Sharma, S.K. and Baral, M.R. (2005) Upper GI Endoscopy in Children in an Adult Suite. Kathmandu University Medical Journal, 3, 111-114.

[30] Tam, P.K. and Saing, H. (1989) Pediatric Upper Gastrointestinal Endoscopy: A 13Year Experience. Journal of Pediatric Surgery, 24, 443-447. https://doi.org/10.1016/S0022-3468(89)80398-7

[31] Megraud, F. (1998) Epidemiology and Mechanism of Antibiotic Resistance in Helicobacter pylori. Gastroenterology, 115, 1278-1282. https://doi.org/10.1016/S0016-5085(98)70101-5

[32] Attia, K.A., N'dri Yoman, T., Mahassadi, A., Bathaix, Y.F., et al. (2004) La prévalence de l'infection à H.pylori en milieu scolaire: Resultats de deux ecoles pilotes. Gastroenterologie Clinique et Biologique, 28, 134. 
[33] Diomande, M.I., Fléjou, J.F., Potet, F., Dago Akribi, A., et al. (1991) Gastrites chroniques et infection à Helicobacter pylori en cote d'ivoire: Etude d'une serie de 277 patients symptomatiques. Gastroenterologie Clinique et Biologique, 15, 711-716.

[34] Bicheler, V., Bruley de Varannes, S., Zerbib, F., Megraud, F. and Galmiche, J.P. (2000) Séroprévalence de l'infection à Helicobacter pylori dans une population adulte saine de l'ouest de la France.

[35] Anicic-Leroy, C. and Evrard-Lemaire, I. Place de la fibroscopie digestive haute chez l'enfant Thèse de Lille: 1993-314. (Résumé).

[36] Toufiki, S. and Sbihi, M. (2008) Apport de la fibroscopie digestive haute chez l'enfant. Thèse de médecine. Faculté de médecine de pharmacie de Marrakech Thèse No. 24.

[37] Pounder, R.E. and Ng, D. (1995) La prévalence de l'infection à Helicobacter pylori dans differents pays. Alimentary Pharmacology \& Therapeutics, 9, 32-39.

[38] Veldhuyzen Van Zanten, S.J.O. (1995) Le niveau socio-économiques, la situation familiale et la profession influencent-ils la prévalence de l'infection par Helicobacter pylori. Alimentary Pharmacology \& Therapeutics, 9, 40-44.

[39] Ilboudo, D., Bougouma, A., Sombié, R., Sawadogo, A., Sanou, I. and Diomande, I. (1998) Infection à H.pylori chez l'enfant en zone tropicale: Aspects endoscopiques et histologiques. Gastroenterologie Clinique et Biologique, 22, 855-857.

[40] Aloulou, H., Maaloul, I., Yaich, S., et al. (2011) La fibroscopie digestive chez l'enfant: Indications et resultats experience d'un service de pédiatrie generale. Journal de Pediatrie et de Puériculture, 24, 111-117. https://doi.org/10.1016/j.jpp.2011.03.006

[41] Chong, S.K.F., Lou, Q., Asnicar, M.A., et al. (1995) Helicobacter pylori dans la douleur abdominale récurrente dans l' enfance: La comparaison des tests de diagnostic et de la thérapie. Pediatrics, 96, 211-215.

[42] Heldenberg, D., Wagner, Y., Heldenberg, E., et al. (1995) Le rôle de Helicobacter pylori chez les enfants souffrant de douleurs abdominales récurrentes. American Journal of Gastroenterology, 90, 906-909.

\section{Submit or recommend next manuscript to SCIRP and we will provide best service for you:}

Accepting pre-submission inquiries through Email, Facebook, LinkedIn, Twitter, etc. A wide selection of journals (inclusive of 9 subjects, more than 200 journals)

Providing 24-hour high-quality service

User-friendly online submission system

Fair and swift peer-review system

Efficient typesetting and proofreading procedure

Display of the result of downloads and visits, as well as the number of cited articles

Maximum dissemination of your research work

Submit your manuscript at: http://papersubmission.scirp.org/

Or contact ojgas@scirp.org 